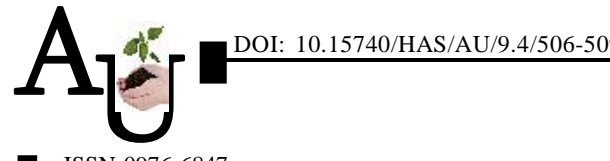

\title{
Study of strategic human resource management (SHRM) towards co-operation and co-ordination among the staff of Karnataka State Horticulture Department in Tumkur district
}

\author{
N. KUMARA AND NEHAL A. FAROOQUEE
}

Article Chronicle: Received :

10.07.2014;

Revised :

08.09.2014;

Accepted :

21.09.2014

\section{Key Words:}

Strategic human resource management, HRM, Co-operation, Co-ordination,

Human resource, Objectives,

Organization
SUMMARY : The research pursues an eminent theme of human resource management, "the co-operation and coordination of human resource activities in an organization". Importance of the HR-activities in an organization cannot be under estimated, as the HR-activities directly or indirectly influence the performance of the organization. The following research will study the co-operation and co-ordination among the staff of Horticulture Department towards achieves the objectives of the organisation. The study will also identify the reasons for conflicts and identify the solutions to solve them. The positivism along with qualitative method of research have been adopted for the study, data will be collected from primary and as well as secondary resources. Research will be pursuing the objectives of the study and will contribute to the vast subject of human resource management, namely the Human resource activities, co-operation and co-ordination among staff that influence on the organizational growth. The Human Resource function has evolved over the years from the labour officer, to the personnel officer, personnel manager and the human resource manager of today. The change in terminology also suggests a change in the objectives and boundaries of the function. The dynamic and competitive business environment resulting from globalization has led a new focus on how human resource should be organized and managed. This has led to the emergence and increase in the use of the term strategic human resource management (SHRM). There has now been a visible convergence between HRM and strategy. Human resources are one of the most important assets in the organizations. Human resources provide an organization a source of sustainable competitive advantage in a highly competitive environment, facing a shortage of talents.

How to cite this article : Kumara, N. and Farooquee, Nehal A. (2014). Study of strategic human resource management (SHRM) towards co-operation and co-ordination among the staff of Karnataka State Horticulture Department in Tumkur district. Agric. Update, 9(4): 506-509.
Author for correspondence :

\section{N. KUMARA}

Department of Extension and Development Studies, Indira Gandhi National Open University, NEW DELHI, INDIA

Email: nkumar278@ gmail.com

See end of the article for authors' affiliations 